\title{
Synthesis and Structure of a Highly Chlorinated C78: C78(2) $\mathrm{Cl} 30$
}

\begin{tabular}{|r|l|}
\hline Journal: & Zeitschrift für Anorganische und Allgemeine Chemie \\
\hline Manuscript ID: & zaac.200900206.R1 \\
\hline Wiley - Manuscript type: & Article \\
\hline $\begin{array}{r}\text { Date Submitted by the } \\
\text { Author: }\end{array}$ & 06-May-2009 \\
\hline Complete List of Authors: & Kemnitz, Erhard; Humboldt-University, Chemistry \\
\hline Keywords: & Fullerene, C78, Cage isomers, Chlorination, Structure elucidation \\
\hline &
\end{tabular}

\section{s scholaroNE" \\ Manuscript Central}




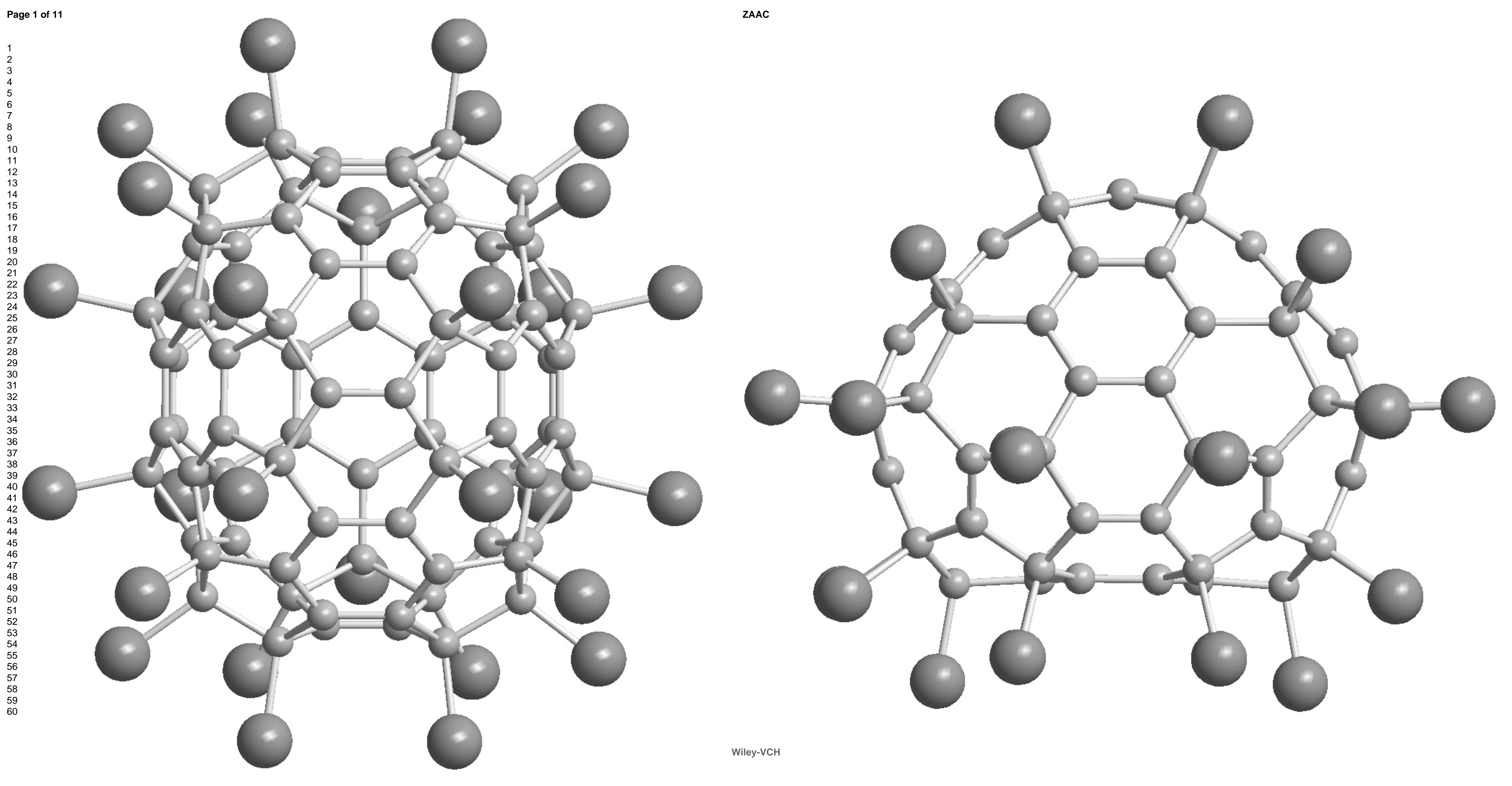




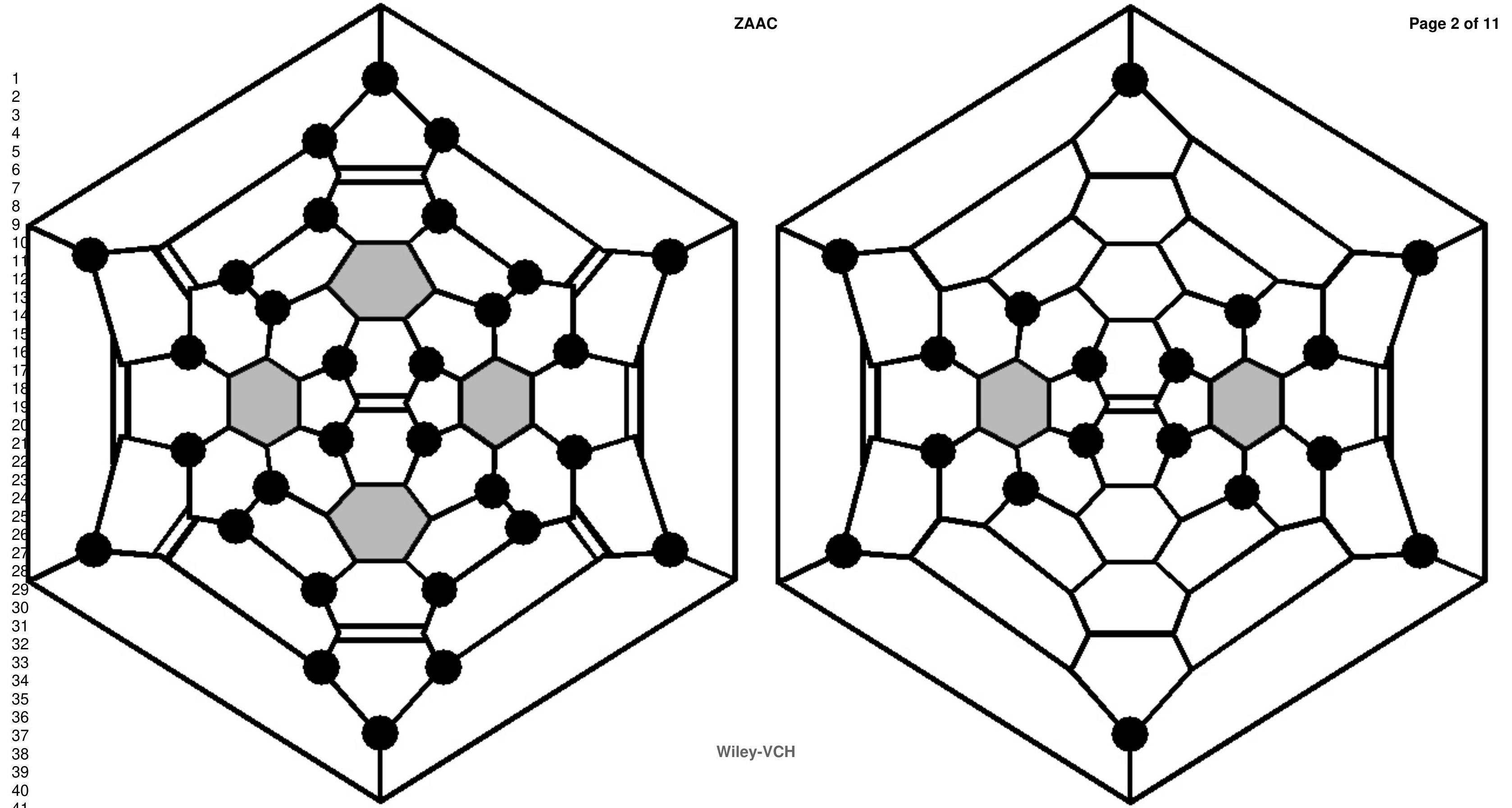



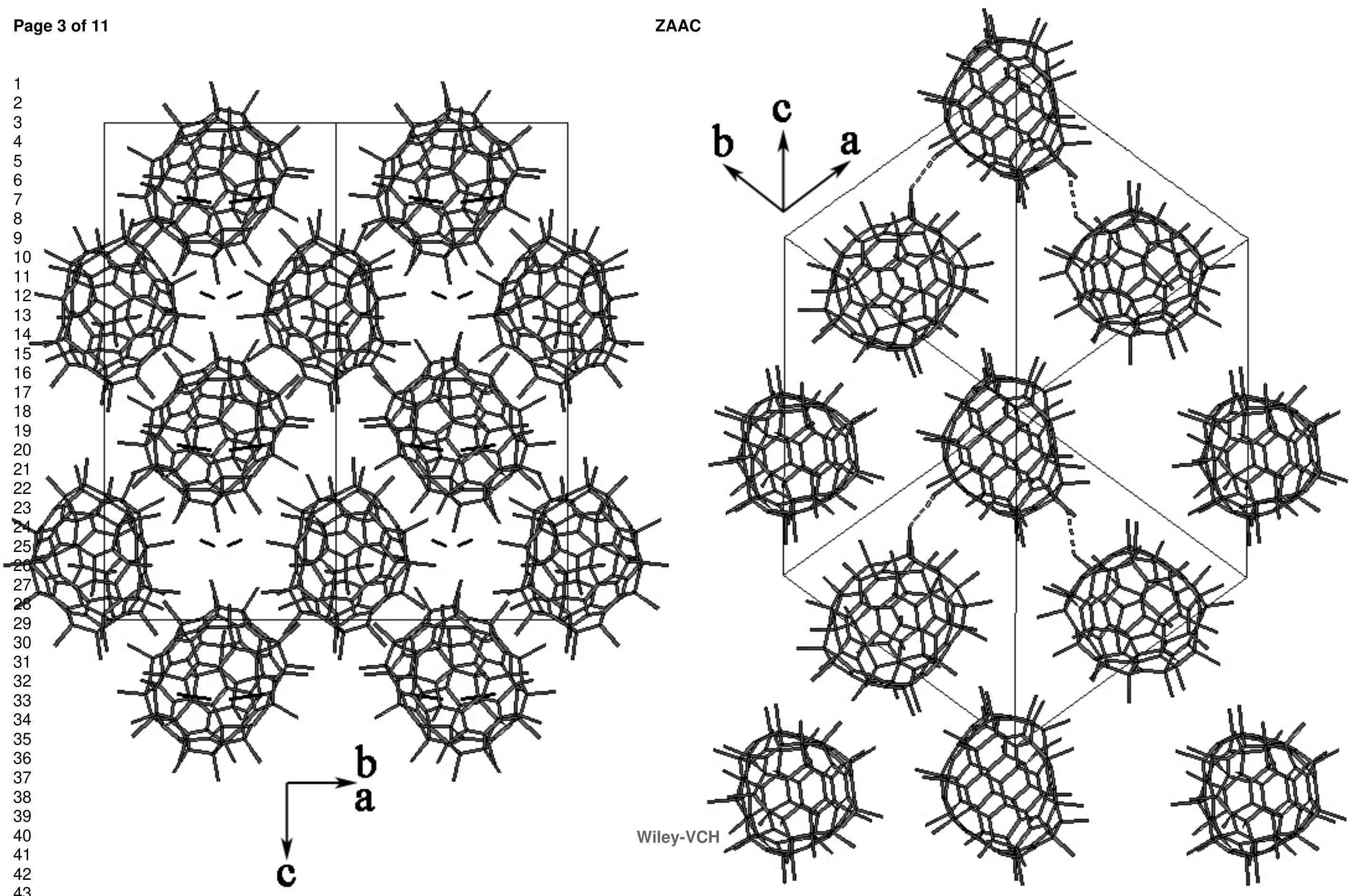


\section{Synthesis and Structure of a Highly Chlorinated $\mathrm{C}_{78}: \mathrm{C}_{78}(2) \mathrm{Cl}_{30}$}

[a] Chemistry Department, Moscow State University, Leninskie Gory, 119991 Moscow, Russia

Fax: +007 4949391240

E-mail: stroyano@thermo.chem.msu.ru

[b] Hefei National Laboratory for Physical Sciences at Microscale \& Department of Materials Science and Engineering, University of Science and Technology of China (USTC), Hefei 230026, China

[c] Institute of Chemistry, Humboldt University, Brook-Taylor Str. 2, 12489 Berlin, Germany

Fax: +4903020937277

E-mail: erhard.kemnitz@chemie.hu-berlin.de

\section{Introduction}

Fullerene halides were among the first structurally investigated fullerene derivatives [1]. On the one hand, they can serve as intermediates for further derivatization of fullerenes. On the other hand, they sometimes facilitate characterization of the connectivity patterns of higher fullerenes. Chlorides of a given fullerene comprise a range of compositions, which lies between those of bromides and fluorides. For example, the known chlorides of $\mathrm{C}_{60}$ contain 6 to 30 attached $\mathrm{Cl}$ atoms [2-5], whereas extreme compositions for bromide are $\mathrm{C}_{60} \mathrm{Br}_{6}[1]$ and $\mathrm{C}_{60} \mathrm{Br}_{24}$ [6], and those reported for fluorides are $\mathrm{C}_{60} \mathrm{~F}_{2}$ and $\mathrm{C}_{60} \mathrm{~F}_{48}$ [7]. Interestingly, lower chlorides of $\mathrm{C}_{60}$ and $\mathrm{C}_{70}, \mathrm{C}_{60} \mathrm{Cl}_{6}$ [2] and $\mathrm{C}_{70} \mathrm{Cl}_{10}$ [8], differ significantly in their properties such as solubility, stability and reactivity from the corresponding higher chlorides, $\mathrm{C}_{60} \mathrm{Cl}_{30}[4,5]$ and $\mathrm{C}_{70} \mathrm{Cl}_{28}$ [9].

In the last years, remarkable progress has been achieved in synthesis and investigation of chlorides of higher fullerenes. Using the reaction of fullerenes with a mixture of $\mathrm{TiCl}_{4}$ and bromine, higher fullerenes $D_{2}-C_{76}(1)$, three isomers of $C_{78}\left(C_{2 v}(2), C_{2 v}\right.$ (3), and $D_{3 \mathrm{~h}}(5)$ ), and $D_{2}-C_{80}$ (2) have been selectively chlorinated, respectively, to $\mathrm{C}_{76} \mathrm{Cl}_{18}[10], \mathrm{C}_{78} \mathrm{Cl}_{18}[11,12]$, and $\mathrm{C}_{80} \mathrm{Cl}_{12}$ [13] in crystalline form thus enabling structural investigation of the connectivity pattern in pristine fullerenes. The chlorinating power of $\mathrm{TiCl}_{4}$ and $\mathrm{Br}_{2}$ mixtures depends on the bromine concentration $[14,15]$, however, on average, it results in the formation of chlorides with lower to middle chlorine content. Higher chlorides can be produced by using stronger chlorinating agents such as $\mathrm{Cl}_{2}$ or some inorganic chlorides ( $\mathrm{ICl}, \mathrm{SbCl}_{5}$ etc.) at higher temperature [16]. For instance, recently chlorination of the mixture of higher fullerenes with $\mathrm{SbCl}_{5}$ resulted in isolation and structural characterization of $\mathrm{C}_{90} \mathrm{Cl}_{32}$ [17]. In this paper, we report the

benzenoid rings in the $\mathrm{C}_{78}$ carbon cage. Therefore, $\mathrm{C}_{78} \mathrm{Cl}_{30}$ represents the highest possible chlorination degree for $\mathrm{C}_{78}$ fullerenes obtained so far.

synthesis and single crystal $\mathrm{X}$-ray study of $\mathrm{C}_{78} \mathrm{Cl}_{30}$ which seems to be the highest chloride of $\mathrm{C}_{78}$ fullerene.

\section{Experimental Section}

$\mathrm{C}_{78}$ fullerene was separated from toluene extraction of the fullerene soot by a two-step HPLC using a Cosmosil Buckyprep column (10 mm i.d. x $250 \mathrm{~mm}$, Nacalai Tesque Inc.) and toluene as the eluent $\left(5.0 \mathrm{~mL} \mathrm{~min}^{-1}\right.$ flow rate, $\left.320 \mathrm{~nm}\right)$. Briefly, in the firststep HPLC a mixed fraction comprised of $\mathrm{C}_{76}$ and two isomers of $\mathrm{C}_{78}$ was collected, which was subjected to the second-step recycling HPLC separation. After two cycles, the major isomer of $\mathrm{C}_{78}$ was successfully obtained with the identification and purity confirmed by MALDI-TOF MS analysis. UV-Vis spectrum of the isolated $\mathrm{C}_{78}$ fullerene dissolved in toluene was recorded on a UVVis-NIR 3600 spectrometer (Shimadzu, Japan).

Approximately $0.3 \mathrm{mg}$ of $\mathrm{C}_{78}$ (2) was placed into a glass ampoule and $0.3 \mathrm{~mL} \mathrm{SbCl}_{5}$ was added. The ampoule was cooled, evacuated, and sealed off. Heating the ampoule at 330-340 ${ }^{\circ} \mathrm{C}$ for 2-3 days produced orange crystals which, after ampoule opening, were separated by decanting $\mathrm{SbCl}_{5}$ and washing with conc. $\mathrm{HCl}$.

The data for crystal with dimensions of $0.20 \times 0.15 \times 0.12 \mathrm{~mm}^{3}$ were collected on an IPDS diffractometer (Stoe) at $100 \mathrm{~K}$ using graphite monochromatized Mo- $\mathrm{K}_{\alpha}$-radiation, $\lambda=0.71073 \AA$ ), $2 \theta_{\max }=58.4^{\circ} ;-28<h, k<28,-43<l<43, R_{\text {int. }}=0.063$. Structure solution and refinement were performed with SHELXS97 and SHELXL97, respectively. Absorption correction was not applied. Crystal data for $\mathrm{C}_{78} \mathrm{Cl}_{30} \cdot \mathrm{Cl}_{2}: M=2071.18$, tetragonal, space group I $\overline{4}, a=20.7619(3), c=31.4440(6) \AA, V=13554.1(4) \AA^{3}, Z=8$, $D_{\text {calc. }}=2.030 \mathrm{~g} \mathrm{~cm}^{-3}, \mu=1.333 \mathrm{~mm}^{-3}$; reflections collected 76817 , independent 18284, $w R_{2}=0.067$ for 18274 reflections and 1019 parameters, $R_{1}=0.030$ for 17653 reflections with $I>2 \sigma(I)$. Whereas $\mathrm{C}_{78} \mathrm{Cl}_{30}$ molecule is fully ordered, the solvated $\mathrm{Cl}_{2}$ molecule is highly disordered between several positions. Crystallographic data (excluding structure factors) for the structure reported in this paper have been deposited with the Cambridge Crystallographic Data Centre as supplementary publication no. CCDC-726149. Copies of the data can be obtained free of charge on application to CCDC, 12 Union Road, Cambridge CB2 1EZ, UK [Fax: (internat.) _-441223-336-033; E-Mail: data_request@ccdc.cam.ac.uk]. 


\section{Results and Discussion}

As shown by Wakabayashi et al. [18], fullerene soot production performed at significantly different conditions could result in fullerene mixtures in which $\mathrm{C}_{78}$ is represented by three cage isomers, $D_{3}(1), C_{2 \mathrm{v}}(2)$, and $C_{2 \mathrm{v}}{ }^{\prime}$ (3), in significantly different ratios. Obviously, these circumstances account for different isomeric compositions of $C_{78}$ as reported by some authors $[19,20]$. In our case, the first of two $\mathrm{C}_{78}$ fractions is the major isomer and contains mainly the isomer $C_{2 \mathrm{v}}-C_{78}$ (2) according to UV-Vis spectra, thus resembling the first $\mathrm{C}_{78}$ fraction described by Diederich et al. in their report concerning isolation and characterization of $\mathrm{C}_{78}$ isomers (1) and (2) [21].

Our X-ray crystallographic study of several single crystals revealed the formation of the same chlorinated derivative of $\mathrm{C}_{78}$, $\mathrm{C}_{78} \mathrm{Cl}_{30}$ (Fig. 1). The $\mathrm{C}_{78}$ carbon cage in $\mathrm{C}_{78} \mathrm{Cl}_{30}$ can be easily recognized as $\mathrm{C}_{78}$ (2) (with the following spiral code: $1,7,9,11,13,24,27,30,32,36,38,40$ [22]) due to the presence of only one horizontal C-C bond in the equatorial belt and the presence of a coronene subunit on the opposite side of the cage (Figure 2). The $\mathrm{C}_{78} \mathrm{Cl}_{30}$ molecule as a whole retains (non-crystallographic) $\mathrm{C}_{2 \mathrm{v}}$ symmetry of the initial $\mathrm{C}_{78}$ (2) cage with a two-fold axis passing through the middle point of the central C-C bond and the centre of the coronene subunit.

\section{Insert Figure 1 here}

Thirty $\mathrm{Cl}$ atoms are attached in 1,2-, 1,3-, and 1,4-positions in carbon hexagons so that the remaining (non-chlorinated) $\mathrm{C}$ atoms form either isolated $\mathrm{C}-\mathrm{C}$ double bonds or aromatic benzenoid rings. There are altogether nine isolated double bonds with an averaged $\mathrm{C}-\mathrm{C}$ distance of $1.33 \AA$ and five flattened benzenoid rings with averaged $\mathrm{C}-\mathrm{C}$ distances of 1.39-1.41 $\AA$. Most uniform $(1.406 \pm 0.006 \AA)$ are $\mathrm{C}-\mathrm{C}$ bonds in the central hexagon of the coronene subunit; its high aromaticity also becomes apparent in a high planarity of this cage region (Fig. 1, right). Four other aromatic benzenoid rings have one or two edge-sharing pentagons in their cage surroundings; $\mathrm{C}-\mathrm{C}$ bonds of hexagon-pentagon junctions are the shortest (1.37-1.38 $\AA$ ) among $\mathrm{C}-\mathrm{C}$ ring bonds thus resulting in less uniform distribution of bondlengths and, therefore, less flat regions of the cage. Unfortunately, a comparison with bondlengths in a non-functionalized $C_{2 \mathrm{v}}-\mathrm{C}_{78}$ (2) molecule is not possible, because the only available data concern a disordered $C_{2 \mathrm{v}}-\mathrm{C}_{78}$ molecule (due to an overlap of two closely situated molecules) in co-crystals with Cu-tetraphenylporphyrin [23].

It is worth noting that all other reported chlorides of $\mathrm{C}_{78}$ were synthesized by chlorination of individual $\mathrm{C}_{78}$ isomers or their mixtures with solutions of $\mathrm{Br}_{2}$ in $\mathrm{TiCl}_{4}[11,12,14]$. They all have the same composition $\mathrm{C}_{78} \mathrm{Cl}_{18}$ and are characterized by the same addition pattern of $18 \mathrm{Cl}$ atoms on slightly different $\mathrm{C}_{78}$ carbon cages. Bromination of $\mathrm{C}_{78}$ (as a by-mixture to $\mathrm{C}_{70}$ ) produced $\mathrm{C}_{78} \mathrm{Br}_{18}$ (co-crystals with isomeric cages 2 and 3 ) possessing the same addition pattern of $18 \mathrm{Br}$ atoms [24]. The attachment of 18 halogen atoms to $\mathrm{C}_{78}$ cages results in three isolated bonds and three aromatic benzenoid rings, whereas the remaining cage has larger regions with delocalized $\mathrm{C}-\mathrm{C}$ bonds. $\mathrm{C}-\mathrm{C}$ bonds in benzenoid rings

\section{Insert Figure 2 here}

are 1.392-1.403 $\AA$ long, i.e. they are in the same range as in the C78Cl30 molecule. Isolated double bonds in the $\mathrm{C}_{78}(2) \mathrm{Cl}_{18}$ molecule can not be calculated reliably because of a statistical disorder resulting in a higher $D_{3 \mathrm{~d}}$ molecular symmetry. A comparison of the addition patterns of $\mathrm{C}_{78}(2) \mathrm{Cl}_{30}$ and $\mathrm{C}_{78}(2) \mathrm{Cl}_{18}$ [11] (Fig. 2) demonstrates that the latter is a substructure of the former being most probably its precursor in the course of chlorination.
Because of the presence of only isolated double bonds and benzenoid rings and also due to an effective shielding of these fragments by the attached $\mathrm{Cl}$ atoms, $\mathrm{C}_{78}(2) \mathrm{Cl}_{30}$ obviously represents the highest possible degree of chlorination of $C_{2 \mathrm{v}}-\mathrm{C}_{78}$ (2). Chlorination of each isolated double bond would generate triple $\mathrm{Cl} \cdots \mathrm{Cl}$ contacts, which are known to be avoided due to strong repulsion [5]. Even in the fullerene fluoride $\mathrm{C}_{60} \mathrm{~F}_{48}$, six isolated C$\mathrm{C}$ bonds are effectively shielded making this compound highly stable. Attempts to further fluorinate $\mathrm{C}_{60} \mathrm{~F}_{48}$ result in a cage destruction [24]. Other structurally similar $\mathrm{C}_{78}$ isomers except for $D_{3}-C_{78}$ (1) would also attach a maximum of $30 \mathrm{Cl}$ atoms with the same addition pattern. Noteworthy, the use of $\mathrm{SbCl}_{5}$ as chlorination agent at elevated temperature seems to facilitate the formation of the highest possible fullerene chloride as already found for the chlorination of $\mathrm{C}_{60}$ to $\mathrm{C}_{60} \mathrm{Cl}_{30}$ [4], $\mathrm{C}_{70}$ to $\mathrm{C}_{70} \mathrm{Cl}_{28}$ [9], and $\mathrm{C}_{90}$ (isomers 46 and 34) to $\mathrm{C}_{90} \mathrm{Cl}_{32}$ [17]. For example, our attempts to further chlorinate $\mathrm{C}_{60} \mathrm{Cl}_{30}$ or $\mathrm{C}_{70} \mathrm{Cl}_{28}$ with liquid $\mathrm{Cl}_{2}$ at ca. $100{ }^{\circ} \mathrm{C}$ did not afford compounds with a higher degree of chlorination.

All $\mathrm{C}-\mathrm{Cl}$ bondlengths lie in the comparatively narrow range of $1.780(3)-1.812(3) \AA$ (av. $1.795 \AA$ ). Six slightly shorter C-Cl bonds (av. $1.782 \AA$ ) involve $\mathrm{Cl}$ atoms having two 1,2 intramolecular $\mathrm{Cl} \cdots \mathrm{Cl}$ contacts. These values are in good agreement with averaged $\mathrm{C}-\mathrm{Cl}$ bondlengths in $\mathrm{C}_{60} \mathrm{Cl}_{30}$ (1.785 [4] and $1.801 \AA$ [5] for the two isomeric molecules) or $\mathrm{C}_{60} \mathrm{Cl}_{28}$ (1.789 $\AA$ [5]) prepared by chlorination of $\mathrm{C}_{60}$ with $\mathrm{SbCl}_{5}$ or ICl. Virtually the same average $\mathrm{C}-\mathrm{Cl}$ distance, $1.796 \AA$, has been found in the $\mathrm{C}_{90} \mathrm{Cl}_{32}$ molecule (in triclinic crystalline modification) obtained by chlorination with $\mathrm{SbCl}_{5}$ [17]. At the same time, all molecules of fullerene chlorides prepared by chlorination with $\mathrm{TiCl}_{4} / \mathrm{Br}_{2}$ mixtures have elongated averaged $\mathrm{C}-\mathrm{Cl}$ distances: $1.83 \AA$ for $\mathrm{C}_{76} \mathrm{Cl}_{18}$ [10], 1.84-1.88 $\AA$ for $\mathrm{C}_{78} \mathrm{Cl}_{18}$ with different $\mathrm{C}_{78}$ isomeric cages [11], and $1.868 \AA$ for cocrystals of $\mathrm{C}_{78} \mathrm{Cl}_{18}$ with a mixture of cage isomers 2 and 3 [14]. We suggested in [14] that such an elongation might be due to the presence of a small fraction of $\mathrm{Br}$ atoms, that could contribute to the apparent elongation of $\mathrm{C}-\mathrm{Cl}$ bonds (in fact, $\mathrm{C}-X, X-\mathrm{Cl}, \mathrm{Br}$ ). Typical $\mathrm{C}-\mathrm{Br}$ bondlengths in fullerene bromides $\left(\mathrm{C}_{60} \mathrm{Br}_{6}[1,16], \mathrm{C}_{60} \mathrm{Br}_{8}[1,16], \mathrm{C}_{60} \mathrm{Br}_{24}[7,16]\right.$, and $\mathrm{C}_{78} \mathrm{Br}_{18}$ [25]) are all about 1.99-2.01 $\AA$. The presence of a few percent of $\mathrm{Br}$ in fullerene chlorides can significantly elongate the obtained $\mathrm{C}-X$ distances because $\mathrm{Br}$ atoms with 35 electrons have larger impact than $\mathrm{Cl}$ atoms (17 electrons) on the position of statistically averaged $X$ atoms. In a more recent work [15], we investigated the chlorination of $\mathrm{C}_{60}$ with $\mathrm{TiCl}_{4} / \mathrm{Br}_{2}$ systematically by varying the $\mathrm{Br}_{2}$ content in the "chlorinating" agent. It has been established that the higher the bromine content was, the higher the $\mathrm{Br} / \mathrm{Cl}$ ratio was found in the obtained crystals of $\mathrm{C}_{60} X_{6}, \mathrm{C}_{60} X_{8}$, and $\mathrm{C}_{60} X_{24}(X-\mathrm{Cl}, \mathrm{Br})$. Noteworthy, $\mathrm{Br}$ atoms were not uniformly distributed among the $\mathrm{C}-X$ bonds of different types. Therefore, the values for $\mathrm{C}-\mathrm{Cl}(\mathrm{C}-X)$ distances in crystals of fullerene chlorides obtained from systems with even low bromine content must be considered critically due to their possible elongation.

\section{Insert Figure 3 here}

Fragments of the packing motifs in crystal structure of $\mathrm{C}_{78} \mathrm{Cl}_{30} \cdot \mathrm{Cl}_{2}$ are shown in Fig. $3 . \mathrm{C}_{78} \mathrm{Cl}_{30}$ molecules are packed in approximately hexagonal layers which are oriented diagonally relative to the unit cell axes. Shortest intermolecular $\mathrm{Cl} \cdots \mathrm{Cl}$ contacts are within 3.13 - $3.42 \AA$ range. Comparatively short intermolecular $\mathrm{Cl} \cdots \mathrm{Cl}$ distances found in most crystal packings of fullerene chlorides $[4,5,10-12,14,17]$ are most probably due to the very small charge on $\mathrm{Cl}$ atoms being nearly zero [26]. Solvated chlorine molecules occupy large tetrahedral holes in the packing of $\mathrm{C}_{78} \mathrm{Cl}_{30}$ molecules; therefore, they are highly disordered between several positions.

In summary, the highly chlorinated $\mathrm{C}_{78}$ fullerene, $\mathrm{C}_{78}(2) \mathrm{Cl}_{30}$, has been obtained by using $\mathrm{SbCl}_{5}$ as chlorinating agent at elevated temperature. In its molecular structure, the $\mathrm{C}_{78}$ carbon cage 
contains only isolated double bonds and aromatic benzenoid rings that most probably implies the highest possible chlorination degree achieved for $\mathrm{C}_{78}$ fullerene. Preparation of highly chlorinated fullerene derivatives and determination of their structures may further serve as an effective way to establish connectivity patterns and study the reactivity of higher fullerenes.

\section{Acknowledgments}

This work was partially supported by the Russian Foundation for Basic Research (09-03-00433 and 09-03-91337) and the Deutsche Forschungsgemeinschaft (Ke 489/26-2). S. Y. thanks the National Natural Science Foundation of China (20801052).

[1] P. R. Birkett, P. B. Hitchcock, H. W. Kroto, R. Taylor, and D. R. M. Walton, Nature, 1992, 357, 479-481.

[2] P. R. Birkett, A. G. Avent, A. D. Darwish, H. W. Kroto, R. Taylor and D. R. M. Walton, J. Chem. Soc., Chem. Commun., 1993, 1230-1232.

[3] N. B Shustova., D. Yu., Chernyshov S. I., Troyanov Mendeleev Commun. 2006, 16, 209-210.

[4] P. A. Troshin, R. N. Lubovskaya, I. N. Ioffe, N. B. Shustova, E. Kemnitz, S. I. Troyanov, Angew. Chem. Int. Ed., 2005, 44, 234-237.

[5] S. I. Troyanov, N. B. Shustova, A. A. Popov, L. N. Sidorov, E. Kemnitz, Angew. Chem. Int. Ed., 2005, 44, 432-435.

[6] F. N. Tebbe, R. L. Harlow, D. B. Chase, D. L. Torn, G. C. Campbell, J. J. C. Calabrese, N. Herron, R. J. Young, E. Wasserman, Science, 1992, 256, 822-825.

[7] R. Taylor, J. Fluorine Chem. 2004, 125, 359-368.

[8] P. R. Birkett, A. G. Avent, A. D. Darwish, H. W. Kroto, R. Taylor, D. R. M. Walton, J. Chem. Soc., Chem. Commun. 1995, 683-684.

[9] S. I. Troyanov, N. B. Shustova, I. N. Ioffe, A. P. Turnbull, E. Kemnitz, Chem. Commun. 2005, 72-74.

[10] K. S. Simeonov, K. Yu. Amsharov, M. Jansen, Angew. Chem. Int. Ed. 2007, 46, 8419-8421.

[11] K. S. Simeonov, K. Yu. Amsharov, M. Jansen, Chem.-Eur. J. 2008, 14, 9585-9590.

[12] K. S. Simeonov, K. Yu. Amsharov, E. Krokos, M. Jansen, Angew. Chem. Int. Ed. 2008, 47, 6283-6285.

[13] K. S. Simeonov, K. Yu. Amsharov, M. Jansen, Chem.-Eur. J. 2009, 15, 1812-1815.

[14] A. V. Burtzev, E. Kemnitz, S. I. Troyanov, Crystallogr. Rep. 2008, 53, 639-644.

[15] S. I. Troyanov, A. V. Burtzev, E. Kemnitz, Crystallogr. Rep. 2009, 54, 242-249.

[16] S. I. Troyanov, E. Kemnitz, Eur. J. Org. Chem. 2005, 49514962.

[17] E. Kemnitz, S. I. Troyanov, Angew. Chem. Int. Ed. 2009, 48, 2584-2587.

[18] T. Wakabayashi, K. Kikuchi, S. Suzuki, H. Shiromaru, Y. Achiba, J. Phys. Chem. 1994, 98, 3090-3091.
[19] R. Taylor, G. J. Langley, T. J. S. Dennis, H. W. Kroto, D. R. M. Walton, J. Chem. Soc., Chem. Commun. 1992, 10431046.

[20] K. Kikuchi, N. Nakahara, T. Wakabayashi, S. Suzuki, H. Shiromaru, Y. Miyake, K. Saito, I. Ikemoto, M. Kainosho, Y. Achiba, Nature 1992, 357, 142-145.

[21] F. Diederich, R. L. Whetten, C. Thilgen, R. Ettl, L. Chao, M. M. Alvarez, Science 1991, 254, 1768-1770.

[22] P. W. Fowler, D. E. Manolopoulous, An Atlas of Fullerenes, Clarendon, Oxford, 1995.

[23] L. Epple, K. Yu. Amsharov, M. Jansen, Fullerenes, Nanotubes Carbon Nanomater. 2009, 17, 67-77.

[24] V. F. Bagryantsev, A. S. Zapol'skii, N. A. Galeva, O. V. Boltalina, L. N. Sidorov, Russ. J. Inorg. Chem. 2000, 45, 1112-1118.

[25] S. I. Troyanov, E. Kemnitz, Eur. J. Org. Chem. 2003, 39163919.

[26] C. B. Hübschle, St. Scheins, M. Weber, P. Luger, A. Wagner, T. Koritsánszky, S. I. Troyanov, O. V. Boltalina, I. V. Goldt, Chem. Eur. J. 2007, 13, 1910-1920.

Received: ((will be filled in by the editorial staff)) Published online: ((will be filled in by the editorial staff)) 


\section{Figure Captions}

Figure 1. Top and side projections of the $C_{2 \mathrm{v}}-\mathrm{C}_{78} \mathrm{Cl}_{30}$ molecule.

Figure 2. Schlegel diagrams of the $\mathrm{C}_{78} \mathrm{Cl}_{30}$ and $\mathrm{C}_{78} \mathrm{Cl}_{18}$ molecules both with $\mathrm{C}_{78}$ (2) isomer cage. Aromatic benzenoid fragments are marked with grey color except for largest limiting hexagons in the both Schlegel diagrams.

Figure 3. Packing in the crystal structure of $\mathrm{C}_{78} \mathrm{Cl}_{30} \cdot \mathrm{Cl}_{2}$ shown within limited depth for clarity (left). Two systems of mutually perpendicular layers can be seen. Separate rods represent some positions of disordered $\mathrm{Cl}_{2}$ molecules. Packing within the layer (right); the shortest intermolecular $\mathrm{Cl} \cdots \mathrm{Cl}$ contacts are shown as dashed lines.

\section{Table of Contents text}

A Highly chlorinated $\mathrm{C}_{78}$ fullerene, $\mathrm{C}_{78}(2) \mathrm{Cl}_{30}$, has been obtained by the reaction of the isomer $\mathrm{C}_{78}$ (2) with $\mathrm{SbCl}_{5}$ in ampoules at 330$340^{\circ} \mathrm{C}$. Single crystal structure determination revealed that the $C_{2 \mathrm{v}^{-}}$ $\mathrm{C}_{78} \mathrm{Cl}_{30}$ molecule contains only isolated double bonds and aromatic

\section{Keywords:}

Fullerene; $\mathrm{C}_{78}$; Cage isomers; Chlorination; Structure elucidation benzenoid rings in the $\mathrm{C}_{78}$ carbon cage thus representing the highest possible chlorination degree for $\mathrm{C}_{78}$ fullerenes obtained so far. 


\title{
Synthesis and Structure of a Highly Chlorinated $\mathrm{C}_{78}: \mathrm{C}_{78}(2) \mathrm{Cl}_{30}$
}

\author{
Sergey I. Troyanov, ${ }^{[a]}$ Nadezhda B. Tamm, ${ }^{[a]}$ Chuanbao Chen, ${ }^{[b]}$ Shangfeng Yang, ${ }^{[b]}$ and Erhard \\ Kemnitz*[c]
}

Dedicated to Prof. Martin Jansen on the Occasion of his 65 birthday

\begin{abstract}
A Highly chlorinated $\mathrm{C}_{78}$ fullerene, $\mathrm{C}_{78}(2) \mathrm{Cl}_{30}$, has been obtained by the reaction of the isomer $\mathrm{C}_{78}$ (2) with $\mathrm{SbCl}_{5}$ in ampoules at 330$340{ }^{\circ} \mathrm{C}$. Single crystal structure determination revealed that the $C_{2 \mathrm{v}^{-}}$ $\mathrm{C}_{78} \mathrm{Cl}_{30}$ molecule contains only isolated double bonds and aromatic

benzenoid rings in the $\mathrm{C}_{78}$ carbon cage. Therefore, $\mathrm{C}_{78} \mathrm{Cl}_{30}$ represents the highest possible chlorination degree for $\mathrm{C}_{78}$ fullerenes obtained so far.
\end{abstract}

[a] Chemistry Department, Moscow State University, Leninskie Gory, 119991 Moscow, Russia

Fax: +007 4949391240

E-mail: stroyano@thermo.chem.msu.ru

[b] Hefei National Laboratory for Physical Sciences at Microscale \& Department of Materials Science and Engineering, University of Science and Technology of China (USTC), Hefei 230026, China

[c] Institute of Chemistry, Humboldt University, Brook-Taylor Str. 2, 12489 Berlin, Germany

Fax: +4903020937277

E-mail: erhard.kemnitz@chemie.hu-berlin.de

\section{Introduction}

Fullerene halides were among the first structurally investigated fullerene derivatives [1]. On the one hand, they can serve as intermediates for further derivatization of fullerenes. On the other hand, they sometimes facilitate characterization of the connectivity patterns of higher fullerenes. Chlorides of a given fullerene comprise a range of compositions, which lies between those of bromides and fluorides. For example, the known chlorides of $\mathrm{C}_{60}$ contain 6 to 30 attached $\mathrm{Cl}$ atoms [2-5], whereas extreme compositions for bromide are $\mathrm{C}_{60} \mathrm{Br}_{6}[1]$ and $\mathrm{C}_{60} \mathrm{Br}_{24}$ [6], and those reported for fluorides are $\mathrm{C}_{60} \mathrm{~F}_{2}$ and $\mathrm{C}_{60} \mathrm{~F}_{48}$ [7]. Interestingly, lower chlorides of $\mathrm{C}_{60}$ and $\mathrm{C}_{70}, \mathrm{C}_{60} \mathrm{Cl}_{6}$ [2] and $\mathrm{C}_{70} \mathrm{Cl}_{10}$ [8], differ significantly in their properties such as solubility, stability and reactivity from the corresponding higher chlorides, $\mathrm{C}_{60} \mathrm{Cl}_{30}[4,5]$ and $\mathrm{C}_{70} \mathrm{Cl}_{28}$ [9].

In the last years, remarkable progress has been achieved in synthesis and investigation of chlorides of higher fullerenes. Using the reaction of fullerenes with a mixture of $\mathrm{TiCl}_{4}$ and bromine, higher fullerenes $D_{2}-C_{76}(1)$, three isomers of $\mathrm{C}_{78}\left(C_{2 \mathrm{v}}(2), C_{2 \mathrm{v}}(3)\right.$, and $\left.D_{3 \mathrm{~h}}(5)\right)$, and $D_{2}-\mathrm{C}_{80}$ (2) have been selectively chlorinated, respectively, to $\mathrm{C}_{76} \mathrm{Cl}_{18}$ [10], $\mathrm{C}_{78} \mathrm{Cl}_{18}[11,12]$, and $\mathrm{C}_{80} \mathrm{Cl}_{12}$ [13] in crystalline form thus enabling structural investigation of the connectivity pattern in pristine fullerenes. The chlorinating power of $\mathrm{TiCl}_{4}$ and $\mathrm{Br}_{2}$ mixtures depends on the bromine concentration $[14,15]$, however, on average, it results in the formation of chlorides with lower to middle chlorine content. Higher chlorides can be produced by using stronger chlorinating agents such as $\mathrm{Cl}_{2}$ or some inorganic chlorides $\left(\mathrm{ICl}, \mathrm{SbCl}_{5}\right.$ etc.) at higher temperature [16]. For instance, recently chlorination of the mixture of higher fullerenes with $\mathrm{SbCl}_{5}$ resulted in isolation and structural characterization of $\mathrm{C}_{90} \mathrm{Cl}_{32}$ [17]. In this paper, we report the synthesis and single crystal $\mathrm{X}$-ray study of $\mathrm{C}_{78} \mathrm{Cl}_{30}$ which seems to be the highest chloride of $\mathrm{C}_{78}$ fullerene.

\section{Experimental Section}

$\mathrm{C}_{78}$ fullerene was separated from toluene extraction of the fullerene soot by a two-step HPLC using a Cosmosil Buckyprep column (10 mm i.d. x $250 \mathrm{~mm}$, Nacalai Tesque Inc.) and toluene as the eluent $\left(5.0 \mathrm{~mL} \mathrm{~min}^{-1}\right.$ flow rate, $\left.320 \mathrm{~nm}\right)$. Briefly, in the firststep HPLC a mixed fraction comprised of $\mathrm{C}_{76}$ and two isomers of $\mathrm{C}_{78}$ was collected, which was subjected to the second-step recycling HPLC separation. After two cycles, the major isomer of $\mathrm{C}_{78}$ was successfully obtained with the identification and purity confirmed by MALDI-TOF MS analysis. UV-Vis spectrum of the isolated $\mathrm{C}_{78}$ fullerene dissolved in toluene was recorded on a UVVis-NIR 3600 spectrometer (Shimadzu, Japan).

Approximately $0.3 \mathrm{mg}$ of $\mathrm{C}_{78}$ (2) was placed into a glass ampoule and $0.3 \mathrm{~mL} \mathrm{SbCl} 5$ was added. The ampoule was cooled, evacuated, and sealed off. Heating the ampoule at $330-340{ }^{\circ} \mathrm{C}$ for 2-3 days produced orange crystals which, after ampoule opening, were separated by decanting $\mathrm{SbCl}_{5}$ and washing with conc. $\mathrm{HCl}$.

The data for crystal with dimensions of $0.20 \times 0.15 \times 0.12 \mathrm{~mm}^{3}$ were collected on an IPDS diffractometer (Stoe) at $100 \mathrm{~K}$ using graphite monochromatized Mo- $\mathrm{K}_{\alpha}$-radiation, $\lambda=0.71073 \AA$ ), $2 \theta_{\text {max }}=58.4^{\circ} ;-28<h, k<28,-43<l<43, R_{\text {int. }}=0.063$. Structure solution and refinement were performed with SHELXS97 and SHELXL97, respectively. Absorption correction was not applied. Crystal data for $\mathrm{C}_{78} \mathrm{Cl}_{30} \cdot \mathrm{Cl}_{2}: M=2071.18$, tetragonal, space group $I \overline{4}, a=20.7619(3), c=31.4440(6) \AA, V=13554.1(4) \AA^{3}, Z=8$, $D_{\text {calc. }}=2.030 \mathrm{~g} \mathrm{~cm}^{-3}, \mu=1.333 \mathrm{~mm}^{-3}$; reflections collected 76817 , independent 18284, $w R_{2}=0.067$ for 18274 reflections and 1019 parameters, $R_{1}=0.030$ for 17653 reflections with $I>2 \sigma(I)$. Whereas $\mathrm{C}_{78} \mathrm{Cl}_{30}$ molecule is fully ordered, the solvated $\mathrm{Cl}_{2}$ molecule is highly disordered between several positions. Crystallographic data (excluding structure factors) for the structure reported in this paper have been deposited with the Cambridge Crystallographic Data Centre as supplementary publication no. CCDC-726149. Copies of the data can be obtained free of charge on application to CCDC, 12 Union Road, Cambridge CB2 1EZ, UK [Fax: (internat.) _-441223-336-033; E-Mail: data_request@ ccdc.cam.ac.uk]. 


\section{Results and Discussion}

As shown by Wakabayashi et al. [18], fullerene soot production performed at significantly different conditions could result in fullerene mixtures in which $\mathrm{C}_{78}$ is represented by three cage isomers, $D_{3}(1), C_{2 \mathrm{v}}(2)$, and $C_{2 \mathrm{v}}{ }^{\prime}(3)$, in significantly different ratios. Obviously, these circumstances account for different isomeric compositions of $\mathrm{C}_{78}$ as reported by some authors $[19,20]$. In our case, the first of two $\mathrm{C}_{78}$ fractions is the major isomer and contains mainly the isomer $C_{2 \mathrm{v}}-\mathrm{C}_{78}$ (2) according to UV-Vis spectra, thus resembling the first $\mathrm{C}_{78}$ fraction described by Diederich et al. in their report concerning isolation and characterization of $\mathrm{C}_{78}$ isomers (1) and (2) [21].

Our X-ray crystallographic study of several single crystals revealed the formation of the same chlorinated derivative of $\mathrm{C}_{78}$, $\mathrm{C}_{78} \mathrm{Cl}_{30}$ (Fig. 1). The $\mathrm{C}_{78}$ carbon cage in $\mathrm{C}_{78} \mathrm{Cl}_{30}$ can be easily recognized as $\mathrm{C}_{78}$ (2) (with the following spiral code: $1,7,9,11,13,24,27,30,32,36,38,40$ [22]) due to the presence of only one horizontal $\mathrm{C}-\mathrm{C}$ bond in the equatorial belt and the presence of a coronene subunit on the opposite side of the cage (Figure 2). The $\mathrm{C}_{78} \mathrm{Cl}_{30}$ molecule as a whole retains (non-crystallographic) $\mathrm{C}_{2 \mathrm{v}}$ symmetry of the initial $\mathrm{C}_{78}$ (2) cage with a two-fold axis passing through the middle point of the central C-C bond and the centre of the coronene subunit.

\section{Insert Figure 1 here}

Thirty $\mathrm{Cl}$ atoms are attached in 1,2-, 1,3-, and 1,4-positions in carbon hexagons so that the remaining (non-chlorinated) $\mathrm{C}$ atoms form either isolated $\mathrm{C}-\mathrm{C}$ double bonds or aromatic benzenoid rings. There are altogether nine isolated double bonds with an averaged $\mathrm{C}-\mathrm{C}$ distance of $1.33 \AA$ and five flattened benzenoid rings with averaged $\mathrm{C}-\mathrm{C}$ distances of 1.39-1.41 $\AA$. Most uniform $(1.406 \pm 0.006 \AA)$ are $\mathrm{C}-\mathrm{C}$ bonds in the central hexagon of the coronene subunit; its high aromaticity also becomes apparent in a high planarity of this cage region (Fig. 1, right). Four other aromatic benzenoid rings have one or two edge-sharing pentagons in their cage surroundings; $\mathrm{C}-\mathrm{C}$ bonds of hexagon-pentagon junctions are the shortest (1.37-1.38 $\AA$ ) among $\mathrm{C}-\mathrm{C}$ ring bonds thus resulting in less uniform distribution of bondlengths and, therefore, less flat regions of the cage. Unfortunately, a comparison with bondlengths in a non-functionalized $C_{2 \mathrm{v}}-\mathrm{C}_{78}$ (2) molecule is not possible, because the only available data concern a disordered $C_{2 \mathrm{v}}-\mathrm{C}_{78}$ molecule (due to an overlap of two closely situated molecules) in co-crystals with $\mathrm{Cu}$-tetraphenylporphyrin [23].

It is worth noting that all other reported chlorides of $\mathrm{C}_{78}$ were synthesized by chlorination of individual $\mathrm{C}_{78}$ isomers or their mixtures with solutions of $\mathrm{Br}_{2}$ in $\mathrm{TiCl}_{4}[11,12,14]$. They all have the same composition $\mathrm{C}_{78} \mathrm{Cl}_{18}$ and are characterized by the same addition pattern of $18 \mathrm{Cl}$ atoms on slightly different $\mathrm{C}_{78}$ carbon cages. Bromination of $\mathrm{C}_{78}$ (as a by-mixture to $\mathrm{C}_{70}$ ) produced $\mathrm{C}_{78} \mathrm{Br}_{18}$ (co-crystals with isomeric cages 2 and 3 ) possessing the same addition pattern of $18 \mathrm{Br}$ atoms [24]. The attachment of 18 halogen atoms to $\mathrm{C}_{78}$ cages results in three isolated bonds and three aromatic benzenoid rings, whereas the remaining cage has larger regions with delocalized $\mathrm{C}-\mathrm{C}$ bonds. $\mathrm{C}-\mathrm{C}$ bonds in benzenoid rings

\section{Insert Figure 2 here}

are 1.392-1.403 $\AA$ long, i.e. they are in the same range as in the $\mathrm{C} 78 \mathrm{Cl} 30$ molecule. Isolated double bonds in the $\mathrm{C}_{78}(2) \mathrm{Cl}_{18}$ molecule can not be calculated reliably because of a statistical disorder resulting in a higher $D_{3 \mathrm{~d}}$ molecular symmetry. A comparison of the addition patterns of $\mathrm{C}_{78}(2) \mathrm{Cl}_{30}$ and $\mathrm{C}_{78}(2) \mathrm{Cl}_{18}$ [11] (Fig. 2) demonstrates that the latter is a substructure of the former being most probably its precursor in the course of chlorination.
Because of the presence of only isolated double bonds and benzenoid rings and also due to an effective shielding of these fragments by the attached $\mathrm{Cl}$ atoms, $\mathrm{C}_{78}(2) \mathrm{Cl}_{30}$ obviously represents the highest possible degree of chlorination of $C_{2 \mathrm{v}}-\mathrm{C}_{78}$ (2). Chlorination of each isolated double bond would generate triple $\mathrm{Cl} \cdots \mathrm{Cl}$ contacts, which are known to be avoided due to strong repulsion [5]. Even in the fullerene fluoride $\mathrm{C}_{60} \mathrm{~F}_{48}$, six isolated C$\mathrm{C}$ bonds are effectively shielded making this compound highly stable. Attempts to further fluorinate $\mathrm{C}_{60} \mathrm{~F}_{48}$ result in a cage destruction [24]. Other structurally similar $\mathrm{C}_{78}$ isomers except for $D_{3}-C_{78}$ (1) would also attach a maximum of $30 \mathrm{Cl}$ atoms with the same addition pattern. Noteworthy, the use of $\mathrm{SbCl}_{5}$ as chlorination agent at elevated temperature seems to facilitate the formation of the highest possible fullerene chloride as already found for the chlorination of $\mathrm{C}_{60}$ to $\mathrm{C}_{60} \mathrm{Cl}_{30}$ [4], $\mathrm{C}_{70}$ to $\mathrm{C}_{70} \mathrm{Cl}_{28}$ [9], and $\mathrm{C}_{90}$ (isomers 46 and 34) to $\mathrm{C}_{90} \mathrm{Cl}_{32}$ [17]. For example, our attempts to further chlorinate $\mathrm{C}_{60} \mathrm{Cl}_{30}$ or $\mathrm{C}_{70} \mathrm{Cl}_{28}$ with liquid $\mathrm{Cl}_{2}$ at ca. $100{ }^{\circ} \mathrm{C}$ did not afford compounds with a higher degree of chlorination.

All $\mathrm{C}-\mathrm{Cl}$ bondlengths lie in the comparatively narrow range of $1.780(3)-1.812(3) \AA$ (av. $1.795 \AA$ ). Six slightly shorter C-Cl bonds (av. $1.782 \AA$ ) involve $\mathrm{Cl}$ atoms having two 1,2 intramolecular $\mathrm{Cl} \cdots \mathrm{Cl}$ contacts. These values are in good agreement with averaged $\mathrm{C}-\mathrm{Cl}$ bondlengths in $\mathrm{C}_{60} \mathrm{Cl}_{30}$ (1.785 [4] and $1.801 \AA$ [5] for the two isomeric molecules) or $\mathrm{C}_{60} \mathrm{Cl}_{28}$ (1.789 $\AA$ [5]) prepared by chlorination of $\mathrm{C}_{60}$ with $\mathrm{SbCl}_{5}$ or ICl. Virtually the same average $\mathrm{C}-\mathrm{Cl}$ distance, $1.796 \AA$, has been found in the $\mathrm{C}_{90} \mathrm{Cl}_{32}$ molecule (in triclinic crystalline modification) obtained by chlorination with $\mathrm{SbCl}_{5}$ [17]. At the same time, all molecules of fullerene chlorides prepared by chlorination with $\mathrm{TiCl}_{4} / \mathrm{Br}_{2}$ mixtures have elongated averaged $\mathrm{C}-\mathrm{Cl}$ distances: $1.83 \AA$ for $\mathrm{C}_{76} \mathrm{Cl}_{18}$ [10], 1.84-1.88 $\AA$ for $\mathrm{C}_{78} \mathrm{Cl}_{18}$ with different $\mathrm{C}_{78}$ isomeric cages [11], and $1.868 \AA$ for cocrystals of $\mathrm{C}_{78} \mathrm{Cl}_{18}$ with a mixture of cage isomers 2 and 3 [14]. We suggested in [14] that such an elongation might be due to the presence of a small fraction of $\mathrm{Br}$ atoms, that could contribute to the apparent elongation of $\mathrm{C}-\mathrm{Cl}$ bonds (in fact, $\mathrm{C}-X, X-\mathrm{Cl}, \mathrm{Br}$ ). Typical $\mathrm{C}-\mathrm{Br}$ bondlengths in fullerene bromides $\left(\mathrm{C}_{60} \mathrm{Br}_{6}[1,16], \mathrm{C}_{60} \mathrm{Br}_{8}[1,16], \mathrm{C}_{60} \mathrm{Br}_{24}[7,16]\right.$, and $\mathrm{C}_{78} \mathrm{Br}_{18}$ [25]) are all about 1.99-2.01 $\AA$. The presence of a few percent of $\mathrm{Br}$ in fullerene chlorides can significantly elongate the obtained $\mathrm{C}-X$ distances because $\mathrm{Br}$ atoms with 35 electrons have larger impact than $\mathrm{Cl}$ atoms (17 electrons) on the position of statistically averaged $X$ atoms. In a more recent work [15], we investigated the chlorination of $\mathrm{C}_{60}$ with $\mathrm{TiCl}_{4} / \mathrm{Br}_{2}$ systematically by varying the $\mathrm{Br}_{2}$ content in the "chlorinating" agent. It has been established that the higher the bromine content was, the higher the $\mathrm{Br} / \mathrm{Cl}$ ratio was found in the obtained crystals of $\mathrm{C}_{60} X_{6}, \mathrm{C}_{60} X_{8}$, and $\mathrm{C}_{60} X_{24}(X-\mathrm{Cl}, \mathrm{Br})$. Noteworthy, $\mathrm{Br}$ atoms were not uniformly distributed among the $\mathrm{C}-X$ bonds of different types. Therefore, the values for $\mathrm{C}-\mathrm{Cl}(\mathrm{C}-\mathrm{X})$ distances in crystals of fullerene chlorides obtained from systems with even low bromine content must be considered critically due to their possible elongation.

\section{Insert Figure 3 here}

Fragments of the packing motifs in crystal structure of $\mathrm{C}_{78} \mathrm{Cl}_{30} \cdot \mathrm{Cl}_{2}$ are shown in Fig. $3 . \mathrm{C}_{78} \mathrm{Cl}_{30}$ molecules are packed in approximately hexagonal layers which are oriented diagonally relative to the unit cell axes. Shortest intermolecular $\mathrm{Cl} \cdots \mathrm{Cl}$ contacts are within 3.13 - $3.42 \AA$ range. Comparatively short intermolecular $\mathrm{Cl} \cdots \mathrm{Cl}$ distances found in most crystal packings of fullerene chlorides $[4,5,10-12,14,17]$ are most probably due to the very small charge on $\mathrm{Cl}$ atoms being nearly zero [26]. Solvated chlorine molecules occupy large tetrahedral holes in the packing of $\mathrm{C}_{78} \mathrm{Cl}_{30}$ molecules; therefore, they are highly disordered between several positions.

In summary, the highly chlorinated $\mathrm{C}_{78}$ fullerene, $\mathrm{C}_{78}(2) \mathrm{Cl}_{30}$, has been obtained by using $\mathrm{SbCl}_{5}$ as chlorinating agent at elevated temperature. In its molecular structure, the $\mathrm{C}_{78}$ carbon cage 
contains only isolated double bonds and aromatic benzenoid rings that most probably implies the highest possible chlorination degree achieved for $\mathrm{C}_{78}$ fullerene. Preparation of highly chlorinated fullerene derivatives and determination of their structures may further serve as an effective way to establish connectivity patterns and study the reactivity of higher fullerenes.

\section{Acknowledgments}

This work was partially supported by the Russian Foundation for Basic Research (09-03-00433 and 09-03-91337) and the Deutsche Forschungsgemeinschaft (Ke 489/26-2). S. Y. thanks the National Natural Science Foundation of China (20801052).

[1] P. R. Birkett, P. B. Hitchcock, H. W. Kroto, R. Taylor, and D. R. M. Walton, Nature, 1992, 357, 479-481.

[2] P. R. Birkett, A. G. Avent, A. D. Darwish, H. W. Kroto, R. Taylor and D. R. M. Walton, J. Chem. Soc., Chem. Commun., 1993, 1230-1232.

[3] N. B Shustova., D. Yu., Chernyshov S. I., Troyanov Mendeleev Commun. 2006, 16, 209-210.

[4] P. A. Troshin, R. N. Lubovskaya, I. N. Ioffe, N. B. Shustova, E. Kemnitz, S. I. Troyanov, Angew. Chem. Int. Ed., 2005, 44, 234-237.

[5] S. I. Troyanov, N. B. Shustova, A. A. Popov, L. N. Sidorov, E. Kemnitz, Angew. Chem. Int. Ed., 2005, 44, 432-435.

[6] F. N. Tebbe, R. L. Harlow, D. B. Chase, D. L. Torn, G. C. Campbell, J. J. C. Calabrese, N. Herron, R. J. Young, E. Wasserman, Science, 1992, 256, 822-825.

[7] R. Taylor, J. Fluorine Chem. 2004, 125, 359-368.

[8] P. R. Birkett, A. G. Avent, A. D. Darwish, H. W. Kroto, R. Taylor, D. R. M. Walton, J. Chem. Soc., Chem. Commun. 1995, 683-684.

[9] S. I. Troyanov, N. B. Shustova, I. N. Ioffe, A. P. Turnbull, E. Kemnitz, Chem. Commun. 2005, 72-74.

[10] K. S. Simeonov, K. Yu. Amsharov, M. Jansen, Angew. Chem. Int. Ed. 2007, 46, 8419-8421.

[11] K. S. Simeonov, K. Yu. Amsharov, M. Jansen, Chem.-Eur. J. 2008, 14, 9585-9590.

[12] K. S. Simeonov, K. Yu. Amsharov, E. Krokos, M. Jansen, Angew. Chem. Int. Ed. 2008, 47, 6283-6285.

[13] K. S. Simeonov, K. Yu. Amsharov, M. Jansen, Chem.-Eur. J. 2009, 15, 1812-1815.

[14] A. V. Burtzev, E. Kemnitz, S. I. Troyanov, Crystallogr. Rep. 2008, 53, 639-644.

[15] S. I. Troyanov, A. V. Burtzev, E. Kemnitz, Crystallogr. Rep. 2009, 54, 242-249.

[16] S. I. Troyanov, E. Kemnitz, Eur. J. Org. Chem. 2005, 49514962.

[17] E. Kemnitz, S. I. Troyanov, Angew. Chem. Int. Ed. 2009, 48, 2584-2587.

[18] T. Wakabayashi, K. Kikuchi, S. Suzuki, H. Shiromaru, Y. Achiba, J. Phys. Chem. 1994, 98, 3090-3091.
[19] R. Taylor, G. J. Langley, T. J. S. Dennis, H. W. Kroto, D. R. M. Walton, J. Chem. Soc., Chem. Commun. 1992, 10431046.

[20] K. Kikuchi, N. Nakahara, T. Wakabayashi, S. Suzuki, H. Shiromaru, Y. Miyake, K. Saito, I. Ikemoto, M. Kainosho, Y. Achiba, Nature 1992, 357, 142-145.

[21] F. Diederich, R. L. Whetten, C. Thilgen, R. Ettl, L. Chao, M. M. Alvarez, Science 1991, 254, 1768-1770.

[22] P. W. Fowler, D. E. Manolopoulous, An Atlas of Fullerenes, Clarendon, Oxford, 1995.

[23] L. Epple, K. Yu. Amsharov, M. Jansen, Fullerenes, Nanotubes Carbon Nanomater. 2009, 17, 67-77.

[24] V. F. Bagryantsev, A. S. Zapol'skii, N. A. Galeva, O. V. Boltalina, L. N. Sidorov, Russ. J. Inorg. Chem. 2000, 45, 1112-1118.

[25] S. I. Troyanov, E. Kemnitz, Eur. J. Org. Chem. 2003, 39163919.

[26] C. B. Hübschle, St. Scheins, M. Weber, P. Luger, A. Wagner, T. Koritsánszky, S. I. Troyanov, O. V. Boltalina, I. V. Goldt, Chem. Eur. J. 2007, 13, 1910-1920.

Received: ((will be filled in by the editorial staff)) Published online: ((will be filled in by the editorial staff)) 


\section{Figure Captions}

Figure 1. Top and side projections of the $C_{2 \mathrm{v}}-\mathrm{C}_{78} \mathrm{Cl}_{30}$ molecule.

Figure 2. Schlegel diagrams of the $\mathrm{C}_{78} \mathrm{Cl}_{30}$ and $\mathrm{C}_{78} \mathrm{Cl}_{18}$ molecules both with $\mathrm{C}_{78}$ (2) isomer cage. Aromatic benzenoid fragments are marked with grey color except for largest limiting hexagons in the both Schlegel diagrams.

Figure 3. Packing in the crystal structure of $\mathrm{C}_{78} \mathrm{Cl}_{30} \cdot \mathrm{Cl}_{2}$ shown within limited depth for clarity (left). Two systems of mutually perpendicular layers can be seen. Separate rods represent some positions of disordered $\mathrm{Cl}_{2}$ molecules. Packing within the layer (right); the shortest intermolecular $\mathrm{Cl} \cdots \mathrm{Cl}$ contacts are shown as dashed lines.

\section{Table of Contents text}

A Highly chlorinated $\mathrm{C}_{78}$ fullerene, $\mathrm{C}_{78}(2) \mathrm{Cl}_{30}$, has been obtained by the reaction of the isomer $\mathrm{C}_{78}$ (2) with $\mathrm{SbCl}_{5}$ in ampoules at 330$340{ }^{\circ} \mathrm{C}$. Single crystal structure determination revealed that the $C_{2 v^{-}}$ $\mathrm{C}_{78} \mathrm{Cl}_{30}$ molecule contains only isolated double bonds and aromatic

\section{Keywords:}

Fullerene; $\mathrm{C}_{78}$; Cage isomers; Chlorination; Structure elucidation benzenoid rings in the $\mathrm{C}_{78}$ carbon cage thus representing the highest possible chlorination degree for $\mathrm{C}_{78}$ fullerenes obtained so far. 